\title{
SELF-DEFENSE OR SELF-DENIAL: THE PROLIFERATION OF WEAPONS OF MASS DESTRUCTION
}

\author{
Major Michael Lacey*
}

\section{INTRODUCTION}

\begin{abstract}
AP News Service: November 3, 2000. Today, United States forces struck suspected nuclear weapons development sites deep inside North Korea. An anonymous source inside the Pentagon revealed that U.S. intelligence assets estimated North Korea was less than three months from testing a crude Hiroshima-type nuclear device. U.S. Secretary of State, Madeleine Albright, appearing at a press conference immediately after the strike, stated that the United States acted in accordance with international law and only under the auspices of self-defense.'
\end{abstract}

The above fictional news account could well be tomorrow's headlines. The United States has recently used military force to strike both at targets of terrorism and at centers where weapons of mass destruction are under development. ${ }^{2}$ Given the proliferation of weapons of mass destruction and terrorist cells in Third World countries, the use of force in the future is a foregone conclusion.

Troubling, however, is the failure of United States policy makers to articulate an accurate legal justification for the use of such force. The current self-defense doctrine is not only weak on its face, but it is unsupported by

* The Judge Advocate General's Corps, United States Army. Presently assigned as a Professor Operational and International Law at The Judge Advocate General's School, United States Army. B.S., 1987 United States Military Academy; J.D., cum laude, 1994 University of Illinois School of Law; L.L.M.,1999, The Judge Advocate General's School. Formerly assigned as Chief of International and Operational Law, Senior Trial Counsel, Chief Administrative Law, 82nd Airborne Division, Fort Bragg, North Carolina, 1994-1997; Funded Legal Education Program, 1991-1994; Battalion S-4, Battalion Support Platoon Leader, Executive Officer, Rifle Platoon Leader, 4/87th Infantry, 25th Infantry Division, Schofield Barracks, Hawaii, 1988-1991. Previous publication: Lane Training in Haiti, Jan.-Apr., INFANTRY MAGAZINE 1998. Editor, The Operational Law Handbook, 1999 and 2000 editions. The opinions expressed by the author in this Article do not necessarily reflect the view of the Judge Advocate General or the Department of the Army.

1. Fictional news account.

2. Sandra Sobeiraj, Clinton Orders Strikes on Afghan, Sudanese Terrorist Sites (visited Sept. 5,1998$)<\mathrm{http} / /$ www.foxnews.com/js_index.sml? context=news/national/0820/ d_ap_08 20_98>. 
international law. The elasticity of the doctrine of self-defense can only stretch so far. For the world's only remaining superpower to claim the necessity of self-defense against a band of Islamic terrorists, armed with little more than small arms, over seven thousand miles away from U.S. borders, stretches the doctrine past logic and into fantasy. State actors should, indeed must, continue to stop serious threats to their national security. Terrorist training camps harbored in other nations and terrorists seeking to develop weapons of mass destruction represent serious threats to the Western democracies. The threat to their indigenous populations is simply too great for such states not to act. The legal justification for this offensive action should then lie in that rationale: the idea that states have the inherent juris ad $v_{\text {vitae }}{ }^{3}$ right prevents the random annihilation of their populations from weapons of mass destruction in the hands of unstable regimes or the murder of their citizens by rogue terrorist bands.

\section{SELF-DEFENSE}

On April 15, 1986, twenty-two United States combat aircraft attacked targets inside Libya which were suspected of supporting international terrorism. ${ }^{4}$ On August 20, 1998, the United States launched seventy-five cruise missiles against suspected terrorist training camps in Afghanistan and a chemical weapons production facility in Sudan. ${ }^{5}$ The United States acted unilaterally without the consent or knowledge of either the Security Council or the General Assembly of the United Nations.

The U.S. strikes against Libya were prompted by U.S. intelligence reports that Libya's leader, Muammar Qaddafi, sponsored the terrorist attack upon a West Berlin discotheque that killed one American and injured two hundred others. ${ }^{6}$ The U.S. raid was carried out by over one hundred attack and support aircraft which hit five targets. All but one of the targets were part of Qaddafi's state sponsored terrorism network, the sole exception being the Libyan air base at Benina which based fighters capable of interdicting the raid.? In commenting on the strike, President Reagan stated, "[S]elf defense is not only our right, it is our duty. It is the purpose behind the mission ... a mission fully consistent with Article 51 of the U.N. Charter."

3. "Right to Life," as translated in BLACK's LAW DictionaRY 854 (7th ed. 1999).

4. FEDERAL RESEARCH DIVISION, LIBYA: A COUNTRY STUDY 229 (1989).

5. Charles Aldinger, U.S. Used Cruise Missiles (visited Sept. 20, 1998) <http://204.202.137.144/sections/world/daily news/strike_hardware 980821 .html >.

6. Federation of American Scientists, Operation El Dorado Canyon (visited Nov. 21, 1998) <http://www.fas.org/man/dod-101/ops/el_dorado_canyon.html>.

7. See id.

8. Id. 
U.S. foreign policy makers were quick to defend the lawfulness of the military action against Libya, Afghanistan, and Sudan. The theme of selfdefense was claimed by U.S. officials as the legal justification for both the Libya and the Afghanistan and Sudan strikes. U.S. Secretary of State Madeleine Albright stated, "[I]f we had not taken this action, we would not have been exercising our right of self-defense. ..." Twelve years earlier, President Reagan had claimed self-defense as the legal justification for the attack on Libya. ${ }^{10}$ Similarly, the United States has relied upon this concept of self-defense to justify intervention in Grenada in 1983 and support of the Contras in Nicaragua in the 1980s. ${ }^{11}$

Unfortunately, in all of the above cases, the United States failed to clear the high legal hurdle set for a nation acting under the guise of self-defense in international law. By incorrectly characterizing these actions as legal under a self-defense doctrine, the United States is opening the international door for abuse by other nations. ${ }^{12}$

In addition, by clinging to this inaccurate legal justification for the use of force against terrorist targets, the United States risks losing international support for an alternative legal theory of intervention; specifically, the affirmative responsibility of a nation-state to use force in order to protect its

9. Secretary of State Madeleine K. Albright, Interview between Albright and CBS-TV Nightly News with Dan Rather Aug. 21, 1998 (visited Sept. 22, 1998) <http://secretary.state. gov/www/statements/1998/98082 lb.html . The U.S. strikes against the targets in Afghanistan and the Sudan represent an attempt to strike at the heart of the Usama Bin Ladin Islamic terrorist group. Usama Bin Ladin, son of a wealthy Saudi Arabian business magnate, leads one of the most dangerous international terrorist organizations. Not only is the Bin Ladin group suspected of masterminding the attacks upon the United States' embassies in Kenya and Tanzania, but also of participating in the following attacks upon the international community:

1) 1992-Conspiring to kill U.S. servicemen who were participating in operation Restore Hope in Yemen.

2) 1995-Assisting an Egyptian terrorist in the assassination of President Mubarak.

3) 1995 - Car bombings against the Egyptian embassy in Pakistan.

4) 1996-Plotting to blow up U.S. airliners over the Pacific.

5) 1996-Conspiring to kill Pope John Paul II and bombing a joint U.S.-Saudi training mission in Riyadh.

See id.; see also Fact Sheet Usama Bin Ladin, released by the Coordinator for Counterterrorism, Dept. of State (visited Sept. 22, 1998) <http://www.state.gov/www/regions/africa/ fs_bin_ Ladin.html > (detailing other terrorist activities of the Usama Bin Ladin terrorist group).

10. See LOUIS HENKIN ET AL., RIGHT AND MIGHT 46 (1989).

11. JOHN N. MOORE ET AL., NATIONAL SECURITY LAW 127-28, 165 (1990).

12. Not only is the United States setting a dangerous precedent by invoking the selfdefense doctrine, but it is also eroding its international credibility. In condemning the Reagan administration's justification for the invasion of Grenada, one scholar wrote: "the clearer the system's rules for evaluating the legality of use of force and the more sophisticated the legal techniques for applying these rules, the more difficult it will become to maintain this Kantianlike cleavage between action as it really is, and as it is claimed to be." Abram Chayes, LAW AND FORCE IN THE NEW INTERNATIONAL ORDERS 21 (1991). 
nationals from nuclear or biological weapons and international terrorists. The spread of weapons of mass destruction may well represent the most serious threat to the national security of the United States. ${ }^{13}$ The United States must concentrate and develop an alternative legal theory for armed intervention, one based on the real rationale for the use of lethal force.

As previously discussed, U.S. policy makers have framed the action taken against Libya, Sudan, and Afghanistan as one of self-defense. Unfortunately, the current U.S. position is insupportable under both customary international law as well as under Article 51 of the United Nations Charter.

The earliest example of what constitutes the standard of self-defense under customary international law stems from the much-analyzed and cited Caroline case. ${ }^{14}$ In 1837, British soldiers crossed into the United States and seized the Caroline, an American ship allegedly aiding Canadian insurrectionists. ${ }^{15}$ Although the issue was eventually resolved through other diplomatic channels, U.S. Secretary of State Daniel Webster gave the quintessential definition of when a state may resort to armed force in selfdefense:

[R]espect for the inviolable character of the territory of independent states is the most essential foundation of civilization .... Undoubtedly it is just, that, while it is admitted that exceptions growing out of the great law of selfdefence do exist, those exceptions should be confined to cases in which the "necessity of that self-defence is instant, overwhelming, and leaving no choice of means, and no moment for deliberation." 16

Even today, Caroline sets the standard for what constitutes anticipatory self-defense under customary international law. First, it clearly illustrates the problem with the United States' reliance upon the legal justification of selfdefense for the recent attacks on terrorist targets. Most importantly, Caroline demands that the threat to the nation-state be imminent. The threat must be massing at the border before the state actor is released from its obligations to respect territorial integrity under international law.

It is difficult, if not impossible, for the United States to argue that the attacks launched on August 20, 1998 were against targets that required an

13. See KathleEN C. BaIley, DOOMSDay WEAPONS IN THE HaNDS OF MANY 6 (1991).

14. See William W. BISHOP JR., INTERNATIONAL LaW 584 (1953).

15. See id.

16. Id. (citing 2 MOORE, INTERNATIONAL LAW 409-14 (1906)) (emphasis added). 
"instant, overwhelming" response and that it had "no choice of means, and no moment for deliberation."17

Other states have attempted unsuccessfully to hide themselves in the Caroline cloak of self-defense. Japan initially sought to describe their invasion of Manchuria in 1931 in terms of self-defense. ${ }^{18}$ The League of Nations quickly dismissed the Japanese argument as superficial and based it on self-interest. The final report by the League stated: "[T]he military operations carried on by Japan against China are out of all proportion to the incident that occasioned the conflict nor on that of the right of self-defense."19

During the Nuremberg trials, several German defendants proffered the defense "that Germany was compelled to attack Norway to forestall an allied invasion, and her actions was therefore preventive." ${ }^{20}$ Significantly, there were Allied plans to seize Norway in order to interrupt German iron ore shipments from Sweden. In dismissing the German defense, the Nuremberg Tribunal actually quoted Caroline, stating that "preventive action in foreign territory is justified only in case of 'an instant and overwhelming necessity for self-defense, leaving no choice of means and no moment of deliberation." "21

The Nuremberg court rejected the defendants' pleas based on the lack of imminence of the possible Allied invasion..$^{22}$ Although the court found that there were plans for a Franco-British attack on Norway, at the time of the German invasion, such an Allied invasion was only a contingency and months away from fruition. ${ }^{23}$ The Nuremberg Tribunal demanded that any nation seeking to utilize the legal justification of self-defense must wait until its proposed aggressor takes some affirmative hostile act in furtherance of the aggression. ${ }^{24}$

Other legal scholars have sought to explain the applicable customary international law standard for the invocation of self-defense as a reasonable standard commonly used in state court. Similar in analysis to the common law of torts, the doctrine queries whether a reasonable state would resort to force facing the perceived threat. If so, the use of armed force is legally justified to prevent the greater harm. ${ }^{25}$

17. BISHOP, supra note 14.

18. LEAGUE OF NATIONS Doc. 1932 VII, 12, 71 (1932).

19. League of Nations O. J. Spec. Supp. 177, V1, at 42 (1933).

20. BISHOP, supra note 14, at 17.

21. Lawrence D. Egbert, International Military Tribunal (Nuremberg), Judgment and Sentences, 41 AM. J. INT'L L. 172, 205 (1947) (quoting The Caroline Case, in 2 JoHN BASSETT MOORE, A DigeST OF INTERNATIONAL LAW 412 (1906)). See also id. at 206 (concerning the planned Allied invasion of Norway).

22. See id. at 206.

23. Id. at 206.

24. See id.

25. Robert H. Jackson, U.S. Attorney General Address Before the Inter-American Bar Association, Havana, Cuba, Mar.27, 1941, 35 AM. J. INT'L L. 1357 (1941). Other "reasonable" 
Not only customary international law but also the United Nations Charter condemns the United States' legal rational as legal justification for the recent attacks upon Sudan and Afghanistan, and the 1986 attack upon Libya. One must begin with the very heart of the United Nations Charter, Article 2(4), to analyze any claim of national self-defense: "All Members shall refrain in their international relations from the threat or the use of force against the territorial integrity or political independence of any state or in any other manner inconsistent with the Purposes of the United Nations." 26

Article 51 of the Charter specifically deals with issue of a nation's use of self-defense. "Nothing in the present Charter shall impair the inherent right of individual or collective self-defense if an armed attack occurs against a Member of the United Nations, until the Security Council has taken the measures necessary to maintain international peace and security."27

Article 51 recognizes that the imminence of the threat may preclude the target nation from seeking immediate permission or notification from the Security Council. It does demand, however, that the nation exercising this inherent right, as soon as reasonably possible, seek assistance from the

states face the threat of international terrorism and are potential targets for weapons of mass destruction in the hands of unstable regimes or terrorist organizations. With the exception of Israel, none of these states have chosen to launch pre-emptive strikes against possible targets. These states have shown no reluctance to act once terrorists have taken their nationals as hostages. Some examples include Belgium's intervention in the Congo in 1960, the French rescue of a busload of French children from Somalia in 1976, and the Israeli raid on Entebbe. See JOHN F. MURPHY, THE UNITED NATIONS AND THE CONTROL OF INTERNATIONAL VIOLENCE 148,188 (1982). But these same states exercise restraint in the absence of an overtly-hostile act on the part of international terrorists. The counter to the above contention that other reasonable states have chosen not to strike international terrorists is the argument that no international actor except for the United States has the military ability to act. However, such a view is incorrect. Several major powers, including Britain, France, Germany, and Russia, possess the ability of power projection beyond their borders. See Jane's Armed Forces of the World, 1998. The stark reality is that these reasonable states apparently do not view the terrorist camps as legitimate targets for self-defense. Even the United Kingdom, which publicly supports such strikes, refused to join the United States in the attack against Libya in 1986.

26. U.N. CHARTER art. 2, para 4.

27. U.N. CHARTER, art. 51. Although the articles appear in direct contradiction to each other, most scholars correctly point out that they are not mutually exclusive. See HANS KELSON, THE LAW OF THE UNITED NATIONS 914 (1951). Of the two, however, Article 2(4) stands out as one of the base principles upon which the United Nations was founded. As the official commentary to Article 2(4) of the Charter states, "[A]s an organization established to maintain international peace and security, its success is obviously dependent on the extent to which its Members respect this basic principle." U.N. CHARTER, Commentary and Documents. It is crucial to understand the underpinnings of Article 51. The raison d'être of the United Nations Charter was to render the unilateral use of force, even in self-defense, subject to the control of the Security Council. See IaN BRownlie, INTERNational LaW aND THE USE OF Force bY STATES 273 (1963). Thus under Article 51, the right to self-defense can only be exercised "until the Security Council has taken measures necessary to maintain international peace and security...." Id. at 274 . 
Security Council. Article 51 specifically requires that measures taken by states in exercise of this right of self-defense must immediately be reported to the Security Council. To date, the United States has not abided by this requirement of Article 51 with regard to the attack upon Libya, Afghanistan, and the Sudan. This is not the first time the United States has exhibited this particular failing under Article $51 .^{28}$

Countless United Nations Security Council Resolutions have rejected nations' attempts to legally justify aggressive acts under Article 51. A common theme resounds throughout all of the decisions made by the United Nations in response to these attempts. Each decision, in the form of a United Nations Security Council Resolution, was that the high threshold required for a state to invoke self-defense was not met. ${ }^{29}$

The Security Council consistently denounces actions taken by a state seeking to invoke the theory of self-defense under Article 51. Although a clear international standard for first use of armed force in self-defense was not announced in these decisions, something equally important did evolve from them. States will often claim self-defense under Article 51 for shallow selfinterest reasons in armed interventions. However, the international community will review such claims under a high standard and condemn those that are not justified. Once condemned, the nation seeking the invocation of Article 51 is left defending its illegal action.

Most international law commentators on Article 51 have set a similar high standard for any state's attempt to use armed force under the guise of self-defense. The commentators are best divided into two distinct groups, the restrictivist view of Article 51, and the expansionist view. The restrictivist standard is best epitomized by Professor Bert V. A. Roling. Roling sums up

28. In Nicaragua v. United States the United States attempted to claim the right of selfdefense on the part of El Salvador. The Intemational Court of Justice addressed El Salvador's responsibility to report under Article 51: "[T] failure to observe the requirement to make a report contradicted a State's claim to be acting on the basis of collective self-defense." Military and Paramilitary Activities in and Against Nicaragua (Nicaragua v. the United States of America), Merits, Judgment, 1986 I.C.J. Reports 122.

29. Israel's attempt to invoke Article 51 when it launched armed incursions into Jordan in 1966 was rejected. The Security Council was quick to dismiss Israel's attempt to use Article 51 for selfish gain. U.N. SCOR 228 Nov. 25 , 1966. Israel did so again after attacking Lebanon in 1974 in an attempt to destroy terrorist camps, which had served as staging bases for attacks into Israeli territory. The Security Council again denied the claim of self-defense. U.N.SCOR 347 April 24, 1974. Finally, Israel again invoked Article 51 as its legal justification for destroying the Iraqi nuclear reactor at Tamuz in 1981- with similar result from an enraged Security Council. U.N. SCOR 488 June 19, 1981. Portugal also claimed legal justification under Article 51 for shelling Senegal in 1969. U.N. SCOR 273 Dec. 9, 1969; as did the British for an armed intervention in Yemen in 1964. U.N. SCOR 188 Apr. 9, 1964. Finally, the former Soviet Union attempted to justify its invasion of Afghanistan in 1980 as self-defense. G.A. Res. 6/2 Jan. 14, 1980. 
the restrictive view of Article 51: "Correspondingly, Art. 2(4) should be read as prohibiting the first use of military power: in resistance against an 'armed attack' the use of force is allowed by virtue of Art. 51, but a State may not initiate the use of force." 30

The standard set for self-defense under the restrictivist interpretation is clear, but perhaps unrealistic: under no circumstances may a state resort to the first use of force. The state must absorb the first blow and then may respond under Article 51. Obviously, under this standard the United States could not claim self-defense for the recent attacks on terrorist targets.

The more accepted expansionist view of Article 51 sets a lower standard for the first use of force by a nation in self-defense. This lower standard is best exemplified by Professor Julius Stone. Stone argues that Article 51 allows states to take pre-emptive armed action when an attack upon their sovereignty is imminent. ${ }^{31}$ One need not wait for the enemy armored columns to begin crossing the border before attacking, if there exists unrefutable proof that the hammer is about to fall. ${ }^{32}$

A similar expansionist view for the use of force under Article 51 is held by Professor John Norton Moore. Moore states that the original drafters of the U.N. Charter were intent upon ensuring that each nation should have this inherent right of self-defense spelled out. The major players after the Second World War-the United States, Britain, France and the Soviet Unionwanted to ensure their ability to intervene in any schematic of collective selfdefense. $^{33}$ The disasters involving Hitler's "absorbing" Austria in 1936 and Czechoslovakia in 1938 were still fresh in the minds of the major powers. They wanted to ensure that this new United Nations had a mechanism for allowing intervention in such a future case-intervention in the name of collective self-defense. ${ }^{34}$

In the international law realm, little case law exists to elaborate on principles stated in treaties or practiced as customary law. Both the Corfu and

30. Bert V. A. Roling, The CurRent Legal Regulation of the Use of Force 5 (1986) (emphasis added).

31. See JULIUS STONE, AGgRESSION AND WORLD ORDER 43 (1958).

32. See JULIUS STONE, LEGAL CONTROLS OF INTERNATIONAL CONFICTS 244 (1984).

33. Interview with Professor John Norton Moore, University of Virginia Law School, in Charlottesville, Va. (Oct. 22, 1998).

34. Although Professor Moore agreed that the imminence of the threat is an underlying assumption before the use of anticipatory self-defense, he felt that such a threshold had already been reached with regard for the U.S. attacks on Afghanistan and Sudan. Professor Moore's theory is that such terrorist organizations represent a continuing threat to the security of the United States-indeed Bin Ladin has allegedly declared war on the United States. Therefore, their attack upon U.S. security is a continuing one and the use of force against them is not so much self-defense as the United States' response in an ongoing war between terrorism and the United States. See id. 
Nicaragua cases elaborate on the high standards required before a state may claim self-defense. ${ }^{35}$

The Corfu case stands as the first instance when the newly-formed International Court of Justice took on the issue of what constitutes selfdefense as defined in Article 51 of the United Nations Charter. On October 22, 1946, warships of Great Britain were attempting an innocent passage through the Corfu Channel off Albania and struck mines. ${ }^{36}$ Subsequently, on November 12, 1946, the British swept the Channel for mines without the consent of the Albanian government-in clear violation of the right of innocent passage. Although the channel was within the territorial waters of Albania and the British ships had a right under international law to travel the channel, they did not have the legal basis to sweep mines. ${ }^{37}$

The British sought to defend their violation of the territorial waters of Albania as an act of self-defense. The Court disagreed:

Between independent states, respect for territorial
sovereignty is an essential foundation of international
relations. The Court recognizes that the Albanian
Government's complete failure to carry out its duties after the
explosions and the dilatory nature of its diplomatic notes are
extenuating circumstances for the action of the United
Kingdom Government. But to ensure respect for
international law, of which it is the organ, the Court must
declare that the action of the British Navy constituted a
violation of Albanian sovereignty. ${ }^{38}$

The Court did not provide examples of what might rise to the level of an armed attack and therefore constitute a legitimate action for a nation to respond under the auspices of self-defense. What the Court did address was the overriding principles of respect for the territorial sovereignty of fellow nations. There has been much academic debate and discussion over the primacy between Article 2(4) (respect for sovereignty) and Article 51 (self-

35. Both cases were heard by the International Court of Justice (I.C.J.). The I.C.J. was established under the Charter of the United Nations immediately after the Second World War. It consists of fifteen judges who are elected by the General Assembly and the Security Council. The Court was established to decide issues of international law between states. Today the I.C.J. stands as the principle authority and arbitrator of disputes between nations. MORRIS L. COHEN ET AL., How TO FIND THE LAW 487 (1992).

36. Corfu Channel Case (Alb. v. Gr. Brit.), 1949 I.C.J. 3.

37. See United Nations Convention on the Law of the Sea, opened for signature Dec. 10, 1982, art. 19, para. 2, U.N. Doc AVCONF.62/122 (1982) (entered into force Nov. 16, 1994).

38. Corfu Case, 1949 I.C.J. at 3. 
defense) of the United Nations Charter. The Corfu case provides the International Court of Justice's view that, absent a clearly imminent threat to a nation's territorial integrity, Article 2(4) trumps a weak case for Article $51 .{ }^{39}$

On April 9, 1984, Nicaragua brought an action before the I.C.J. which included allegations that the United States was directly responsible for supporting insurgent groups seeking to overthrow the popularly elected Nicaraguan government. ${ }^{40}$ The basis for the allegations was U.S. support of the Contras, a right-wing group operating out of El Salvador and conducting frequent raids into neighboring Nicaragua. ${ }^{41}$

In summary, the United States claimed the right of collective selfdefense to justify this covert use of force against Nicaragua. The Court's opinion provides a useful definition of what constitutes an "armed attack" under Article 51 of the United Nations Charter:

In the case of individual self-defense, the exercise of this right is subject to the State concerned having been the victim of an armed attack. Reliance on collective self-defense of course does not remove the need for this. There now appears to be general agreement on the nature of the acts which can be treated as constituting armed attacks. In particular, it may be considered to be agreed that an armed attack must be understood as including not merely action by regular armed forces across an international border, but also the sending by or on behalf of a State of armed bands, groups, irregulars or mercenaries, which carry out acts of armed force against another State. ${ }^{42}$

39. See id.

40. Cumulative Digest of U.S. Practice ININTERnational law, 1981 Digest at 3326 (1981).

41. Before the Court's final ruling, the United States had sought to withdraw from the Court's compulsory jurisdiction (to which it had earlier consented). On November 26, 1984, by a vote of 11 to 5 , the I.C.J. ruled against the U.S. position and determined that the I.C.J. did have jurisdiction over the dispute. The United States refused to acknowledge the I.C.J.'s ruling and the United States made no submissions on the merits in front of the Court. The U.S. position on the controversy was described by Abraham D. Sofaer, the Chief Legal Advisor for the Department of State. The U.S. legal justification for their support of the Contras was upon the basis of collective self-defense resulting from Nicaragua's use of force against neighboring El Salvador. Abraham D. Sofaer, Address Before the American Society of International Law (Apr. 22, 1988) in Cumulative Digest OF U.S. PRACTICE IN INTERNATIONAL LAW 1988 DIGEST.

42. Nicaragua v. United States, 1986 I.C.J. 103. The opinion also provides an excellent quote directly applicable to the U.S. action against Afghanistan and Sudan:

On the other hand, if self-defense is advanced as a justification for measures which would otherwise be in breach both of the principle of customary international law and of that contained in the Charter, it is expected that the conditions of the Charter be respected. Thus for the purposes of enquiry into the 
Interestingly, the I.C.J.'s one positive finding for the U.S. position, in the Nicaraguan incident is contrary to the current U.S. claim of self-defense against the terrorists in Libya, Afghanistan, and Sudan: "As stated above, the court is unable to consider that, in customary international law, the provision of arms to the opposition in another State, constitutes an attack." ${ }^{, 43}$ The United States, therefore, had not committed an armed attack upon Nicaragua by virtue of supplying arms and supplies to the Contras. Simply put, supplying arms to a faction bent upon hostile overthrow of a regime does not rise to the high level which would constitute an armed attack and thereby justify the invocation of self-defense. Mere preparation of the potentially hostile force is not enough. If this is the case, however, the current U.S. policy of selfdefense is indefensible from an international legal standpoint. Certainly the United States was committing a more aggressive act towards Nicaragua by supplying arms and training the Contras than the nations harboring the suspected terrorists in Afghanistan, Sudan, and Libya committed toward the United States. Yet the I.C.J. specifically determined that the United States' conduct was not egregious enough to rise to the level of armed attack. Therefore, the lesser form of aggression practiced by the suspected terrorists in the above named countries (mere preparation), could not rise to the level of an armed attack upon the United States.

The weakness of the current U.S. position becomes even clearer when one analyzes the definition of self-defense used by the U.S. armed forces. Chairman of the Joint Chief of Staff Instruction (CJCSI) number 3121.01 contains the standing rules of engagement for U.S. forces. Enclosure A to CJCSI 3121.01 gives the official definition of when U.S. forces may respond with deadly force in self-defense. Specifically: "A commander has the authority and obligation to use all necessary means available and to take all appropriate actions to defend that commander's unit and other U.S. Forces in the vicinity from a hostile act or demonstrated hostile intent." ${ }^{\text {4 }}$

customary law position, the absence of a report may be one of the factors indicating whether the State in question was itself convinced it was acting in selfdefense.

Id. at 105. The Court concludes that the condition sine qua non required for the exercise of collective self-defense was not met by the United States. See id.

43. Id. at 119.

44. Chairman of the Joint Chief of Staff Instruction, Enclosure A (A-4) 1994. Rules of Engagement are directives issued by competent military authority to delineate the circumstances and limitations under which its own naval, ground, and air forces will initiate and/or continue combat engagement with other forces encountered. They are the means by which the National Command Authority (NCA) and operational commanders regulate the use of armed force in the context of applicable political and military policy and domestic and international law. See id. (emphasis added). 
Obviously, the definition of hostile act and of hostile intent is crucial if one is to clearly understand when one can act in self-defense. CJCSI 3121.01 provides both:

Hostile Act: A hostile act is an attack other use of force by a foreign force or terrorist unit (organization or unit) against the United States, U.S. forces, and in certain circumstances, U.S. citizens, their property U.S. commercial assets, or other designated non-U.S. forces, foreign nationals and their property. ${ }^{45}$

The hostile act will have already occurred before U.S. forces have had the opportunity to use force. The definition of hostile intent gives the rules for first use of deadly force by U.S. forces:

Hostile intent: Hostile intent is the threat of imminent use of force by a foreign force or terrorist unit (organization or individual) against the United States, U.S. forces, and in certain circumstances, U.S. citizens, their property, U.S. commercial assets, or other designated non-U.S. forces, foreign nationals and their property. ${ }^{46}$

The definition of "hostile intent" is most useful in analyzing the U.S. position on what constitutes self-defense. Notice how the drafters of the standing rules of engagement demanded the threat to be imminent before U.S. forces may use deadly force. The flashback to the Caroline case, as well as Article 51 of the U.N. Charter, is apparent.

The hypocrisy of the current U.S. claim of self-defense is readily evident when viewed in contrast to the concrete rules provided to the United States armed forces. The rules provided to the U.S. military demand that any threat be close at hand before it is allowed to use deadly force. While no hard and fast rule for what amounts to imminence can be or should be promulgated, some examples are useful. A terrorist truck, full of explosives bearing down on a Marine sentry guarding a U.S. compound, would no doubt qualify as an imminent threat and justify the use of deadly force. It is difficult to view foreign nationals conducting terrorist training in a Third World country (Afghanistan) with the same degree of impending threat-especially terrorist forces which have not been declared a hostile force per CJCSI 3121.01 .

There exists a hidden central theme behind the requirement for the immediacy of the threat prior to the use of force presented by Caroline 
(customary international law), Article 51, and the United States' own CJCSI 3121.01. That theme is that there exists no time to take any other measuretherefore one may resort to force. The soldiers are massed on the borders, the terrorist truck is bearing down on the sentry or a foreign national is pointing a weapon in the direction of U.S. soldiers. Diplomacy, counterintelligence, security measures, and other early warning systems have failed. The last resort is the stark reality of armed force.

Some legal scholars seek to equate the terrorist operating in Third World countries as the equivalent of a state actor. As previously discussed, Professor Moore represents this school of thought, arguing that the United States and such organizations are engaged in an ongoing struggle, so any use of force is legitimate. ${ }^{47}$

The advantage of granting the status of a state to a terrorist organization is obvious. Treaties and bilateral obligations only exist between state actors, not between organizations (such as terrorist groups) and states. If state status is granted to the terrorist organization, the case for self-defense becomes much stronger. Unfortunately, little real evidence exists to equate the Usuma Bin Ladin terrorist organization to the functional equivalent of a state.

Traditionally, for purposes of international law, a state should have the following criteria: a) a permanent population; b) a defined territory; c) a government; and d) the capacity to enter into relations with other states. ${ }^{48}$ Membership in the United Nations is provided for in the Charter only for "peace loving states." 49

Few, if any, terrorist groups can claim even one of the above criteria. Although a terrorist group may be composed of exclusively one nationality (such as the Irish Republican Army), it is by no means permanent, with terrorist members joining and leaving as they please. Significantly, when members of a terrorist organization leave the group they do not carry the designation as a former member abroad with them-as would the citizen of a nation-state.

Most terrorist organizations are constantly on the move, with no definite territory, and with cells in multiple countries. The coordinator for Counterterrorism for the United States Department of State describes the Bin Ladin network as "multi-national and as having established a worldwide presence." 50 There are currently Bin Ladin terrorist cells in Afghanistan, Bosnia, Chechnya, Tazikstan, Somalia, Yemen, and Kosovo. ${ }^{51}$

47. Interview with Professor Moore, supra note 33.

48. WILLIAM W. BISHOP JR., INTERNATIONAL LAW 210 (1962).

49. U.N. CHARTER art. 4.

50. Fact Sheet Usama Bin Ladin-released by Coordinator for Counterterrorism, Department of State (visited Sept. 22, 1998) <www.state.gov/www/regions/ africa/fs_ bin Ladin.htlm>.

51. Arabic News, U.S. Military Strikes Against Afghanistan and Sudan Targets in Self 
The terrorist organization has no traditional governmental apparatus as required for international recognition as a state. Its policies are usually dictated by either their financier (Bin Ladin) or by their state sponsor (Qaddafi).

Finally, the terrorist organization lacks the capacity to enter into legitimate agreements with other states. Certainly, some Islamic fundamentalist terrorist organizations do have informal agreements for financial and material support from their state sponsors (such as Libya, Syria, and Iran). However, these support agreements do not rise to the level of legitimate intemational agreements. The terrorist organization, in such circumstances, is not an independent actor, but is merely acting as an agent of the supporting state. While Iran may be capable of entering into an international agreement with the United States, the Hezbullah it supports in Lebanon cannot.

Given all of the above, the argument that the United States can equate the terrorist organization with a state actor is flawed. The United States is not . willing to grant state status to Usama Bin Ladin's organization for the purpose of negotiation. To pretend that terrorists are the equivalent of a state for striking them in "self-defense" is hypocrisy.

Others argue that since the states from which they are operating permit the terrorist group to exist and train inside their borders, they accept the responsibility associated with it. This principle of international law is widely accepted and is known as vicarious state responsibility; however, a state is responsible vicariously for every act of its own forces, of the members of its government, of private citizens, and of aliens committed on its territory. Vicarious responsibility is limited to the duty to exercise reasonable care to prevent the commission of illegal acts against foreign states, and, if committed, to punish the wrongdoers and compel them to make whatever reparation possible. ${ }^{52}$

Unfortunately, once again the Bin Ladin group does not lend itself to a clean vicarious responsibility analysis. An argument that the government of Sudan sanctioned Bin Ladin terrorist activities is insupportable. Bin Ladin was expelled from Sudan by its government in $19966^{53}$ Interestingly, each of the above countries in which Bin Ladin has a terrorist cell is either involved in internal civil unrest or completely lacking any form of effective central government. With no central authority to either sanction or support the activities of the Bin Ladin movement, the vicarious responsibility argument for the use of force breaks down. Not only does the Bin Ladin organization 
fall short of assuming the identity of a state, but in most cases the "states" from which it operates lack many of the criteria of qualifying for international state status.

A good example is the presence of the Bin Ladin organization in Afghanistan. Those who would argue that the government of Afghanistan has permitted Bin Ladin's terrorists open access to their country fail to recognize the current fragmented nature of this war-torn nation. One of the many sects, religious and otherwise, battling for control of Afghanistan is the Taliban. "The Taliban force represent only one of the many factions competing for control in the on-going civil war for Afghanistan." 54 Currently, the Taliban control large sections of rural Afghanistan where Bin Ladin operates his terrorist camps. Ladin has been an ardent supporter of the Taliban since its guerrilla campaigns against the former Soviet Union.

However, even the Taliban has warned Bin Ladin not to attack any other state and even moved him from one location to another as "to keep a watchful eye on him." To argue that the "state" of Afghanistan is offering covert support to the Bin Ladin movement and is therefore vicariously responsible for its violent actions is to ignore the chaotic status quo which currently exists there. ${ }^{56}$

The terrorists in Afghanistan, as well as the terrorist training camps the United States struck in Libya in 1986, represent a real threat to U.S. security. Such terrorists could have infiltrated the United States or struck other U.S. targets such as U.S. embassies in Kenya and Tanzania. Perhaps such an attack was scheduled to have occurred within weeks or even days of the U.S. attack. Still the high threshold of imminence was not met. There existed other institutional "self-defense" mechanisms which the terrorists would have had to breech (or at least attempt to breech) before the nature of their threat rose to the requisite level of imminence required for self-defense: security safeguards, such as U.S. Customs, various airport security measures, the U.S. anti-terrorist intelligence network and that of U.S. allies, as well as various diplomatic channels.

The desirability of striking such terrorist targets before they can reach such security safeguards is self-evident. However, the risk in doing so in the lack of any immediate impending attack is also patently obvious. In the absence of a clear immediate threat, explaining one state's violation of another state's territorial sovereignty can lead to some unsubstantiated claims. The former Soviet Union's invasion of Afghanistan in 1981 serves as the best example. The Soviet Union claimed that the Afghanistan government had

54. U.S. Military Strikes Against Afghanistan and Sudan Targets, supra note 51.

55. Speech from Kenneth Katzman, Middle East and terrorism expert, (visited Oct. 2, 1998) <asia.gov/topical/pol/terror/ 98082404 .ltm>.

56. Note that the author's above assertions concerning Usama Bin Ladin are all based upon unclassified facts and sources. 
requested the Soviet intervention in 1979 pursuant to a treaty of friendship between the two states. The argument was one of collective self-defense. ${ }^{57}$ Without the sine qua non of imminence, anticipatory self-defense becomes nothing more than a slippery slope of naked aggression. As one legal scholar said, "I accept the view that one has to be very careful in regard to anticipatory action and in principle exclude it in view of the risks involved." 58

\section{JURIS AD VITAE}

If not self-defense, then what is the proper legal justification for the United States' use of force against terrorist targets or weapons of mass destruction in the hands of fanatical, dangerous regimes? Since the fall of the Soviet Union and the end of the Cold War, these dual devils represent the greatest threat to the security of the United States. To deny states the ability to strike such targets, because they have not met the high legal standards required by the international community for self-defense, is to give the Bin Ladins and Saddam Hussains permission to continue their lethal activities.

The answer for the legal justification lies in the real rationale for the use of lethal force against such targets. The United States has elected to use force against such targets not because of the threat they pose to the United States as a sovereign nation, but rather because of the threat they pose to U.S. nationals, both inside and outside of the United States. If this is the underlying reasoning for the use of such force, the legal justification should center upon that rationale.

The concept of juris ad vitae, literally the "right to life," focuses on a state's affirmative responsibility to protect its citizens both at home and abroad from lethal force. Juris ad vitae is far from being a novel concept in international law; it has its roots in the related concept of state responsibility. Many early political philosophers recognized the state's pro-active duty to safeguard its citizens.

The concept of a state's responsibility towards its citizens was first recognized by the early Greek philosophers Plato and Aristotle. Plato's Republic still stands as one of the premier ancient works on the interplay between the state and man. The Republic expanded on Plato's idea of the perfect state. The ultimate goal and reason for the existence of the state for Plato was for the positive furtherance of goodness. ${ }^{59}$

57. See HILAIRE MCCOURBrey \& Nigel D. WHITE, INTERNATIONAL LAW AND ARMED CONFLICT 26-27 (1992).

58. MANFORD LACHS, THE DEVELOPMENT OF GENERAL TRENDS OF INTERNATIONAL LAW IN OUR TIME, 1980-1984 Recueil Des Cours 163.

59. See Robert H. MURRay, The History of Political Science from Plato to the PRESENT 1 (1925). Plato saw the perfect state as one where the citizens are joined in an indistinguishable union with their polis. See id. Both existed to serve the other. See id. The 
Plato compared the concept of a state to the idea of an extended family - with rights and obligations flowing both ways. "He treated the City States as a mere enlarged household, and had spoke as if the master of slaves, the head of the household and the king or citizen ruler of a state only differed in the number of those they ruled." 60

Plato argued that it was the affirmative duty of the state to seek out and eradicate any threat to its existence. One translation of a passage from The Republic states: "The action of the state may be positive or preventive. It may stimulate the good life or it may remove hindrances to it. As sickness is a symptom of the disease of the soul, so crime is a symptom of the disease of the body." 61

For Plato, the state and the individual were joined in an inseparable union. The state is a moral and spiritual organism fitted to absorb the feelings and thoughts of its citizens. ${ }^{62}$

Plato's state and individual unity theory lays the foundation for the juris ad vitae legal justification for striking the terrorists targets-not under a theory of self-defense, but because of the affirmative obligation the state owes to its citizens. Indeed, Plato would argue that it was this correspondence of rights and duties (between the state and the citizen) that form the basis for the unity of state and man.

Aristotle's Politics stands as a further refinement of Plato's ideas, but yet offers his own unique perspective on what responsibilities the state owes its citizens. Aristotle considered the state as a product of human nature, "[t]he state comes into being for the sake of mere life, but exists (or continues to exist) for the sake of the good life ...."63

He also recognized the crucial responsibility of the state to provide protection to its citizens. For Aristotle, this was one of the raison d'être for the existence of the state. "The individual requires the state to give him a legal existence: apart from the state he has neither safety nor freedom." ${ }^{164}$

Interestingly, Aristotle directly addressed when a state, or city-state in ancient Greece, may retaliate for a wrong committed against the citizen. As one commentator on Aristotle's Politics noted: "Aristotle, referring to the Pythagorean doctrine that justice was served by a random retaliation on one's neighbors, criticizes this definition on the grounds that retaliation does not

state's affirmative obligation was to protect the man and to raise him to a higher level of consciousness through philosophy, education, and the creation of great works of art; and the duty of the man was to serve his fellow man through service to the state. See id.

60. WILlIAM L. NEWMAN, THE POlitics OF ARISTOTLE 28 (1887).

61. MURRAY, supra note 59, at 12.

62. See id. at 8.

63. ARIStotle, Politics iii. $9 \$ 14,1280$ b.40, (William L. Newman, trans., Oxford, Clarendon Press 1887).

64. J. K. BLUNTSCHLI, THE THEORY OF THE STATE D2 (1885). 
harmonize with the concept of either distributive justice or corrective justice, which he invokes as the essential criteria."

In Aristotle's view, the reprisal was "justice served" only if the retaliation destroyed the original source of the amelioration-corrective justice. In other words, if five hundred Spartans raided Athens and killed one thousand innocent Athenian citizens, justice was not served by Athenians killing an equal number of innocent citizens of Sparta. However, if the original five hundred Spartans could be found and executed, then the original source of the harm was destroyed and corrective justice was accomplished.

The above principles provide an analytical, ancient foundation for the concept of juris ad vitae. Both Plato and Aristotle linked the individual and the state in a close symbiotic relationship. Both listed and defined the duties that the individual citizen owed the Greek polis or city-state. But both also recognized that the very origins and foundations of the state rested upon its most basic duty to its citizens - the preservation of their continued existence.

Turning from the ancient to the more modern, the great English political philosopher Thomas Hobbes also wrote about the state's responsibility to safeguard the lives of its citizens. Thomas Hobbes was the first philosopher to use the idea of a social contract to describe the relationship between the individual and the state. ${ }^{66}$ For Hobbes, man's natural state was as a selfish, brutal, power-hungry creature. ${ }^{67}$ The only way man could reach a state of peace in this "war of all against all" was to create a state to implement the rule of law. ${ }^{68}$

In Leviathan, Hobbes reiterates that because the basic state of nature of man is insecure, the principle goal of the contract between the individual and the state is to eliminate that insecurity. ${ }^{69}$ Man relinquishes his individual

65. Colman PhILIPION, THE INTERNATIONAL LAW AND CuSTOM OF ANCIENT GREeCE AND ROME 217 (1911). Aristotle's view of this corrective or distributive justice concept is a key to understanding his view of the responsibility of the state towards its citizens. For Aristotle, punishment was only just if it was directly related to the wrong suffered. Aristotle saw punishment as a scale-with the original wrong tipping the balance of the scale towards injustice. The only way to correct the inequity was to counterbalance the scale with punishment towards the original transgressor--this was corrective or distributive justice. This was a novel concept in ancient Greece where random acts of retaliation for acts of aggression were commonplace. Aristotle saw retaliation, regardless if done by either an individual or a state, as worse than useless, because it only served to tip another scale towards injustice. This then was the role of the state, to keep the scales balanced. Aristotle would see the modern day terrorist act as placing a weight on the scales-scales which can only be set right by a counteract (not retaliation) on the part of the state.

66. See Kent F. MOORS, AN InTROduction to the Study of Politics 10 (1992).

67. See Norberto Bobbio, THOMas HobBes aND THE NATURAL LaW CONDITION 40-41 (1993).

68. Hobbes wrote: "The preliminary condition to attaining peace is thus a universal compact through which human beings can leave the state of nature and institute a state that will allow everyone to follow the dictates of right reason ...." Id. at 46-47.

69. See ThOMas Hobbes, LeVIATHAN XVII 227 (C. B. MacPherson ed., 1985). 
freedom so that he may have the safety and security of the sovereign. For Hobbes, any outside threat to the society that would threaten to return that insecurity must be dealt with harshly by the sovereign. Failure to do so would invalidate the entire underlying principle between the state and the individual; namely, the individual gives up his freedom of action to gain the security and safety of a system of laws. Hobbes would view the juris ad vitae legal justification for attacks upon international terrorist targets as a mere fulfillment of the duty of the state to its citizens.

John Locke further elaborated on Hobbes's social contract theories, but added the idea of "natural law." Locke did not see the natural state of man as a chaotic pursuit of power, but instead man's reckless nature was regulated by natural laws from which man derived natural rights. ${ }^{70}$ The supreme duty of the state was to protect these natural rights. Locke defines some of the most obvious natural rights as the right to life, food, family, and property. ${ }^{71}$ For Locke, the laws of nature were given to man by God and were codified in the Christian Bible. Locke wrote that man's adherence to these natural laws would result in the perfect state of harmony and justice. But he also at the same time recognized that not all men would obey these natural laws, and that the state must take positive measures to enforce them. ${ }^{72}$

Under Locke's ideals, the individual was prohibited from taking any action to harm his fellow man. However, this prohibition did not apply to the state since it was tasked to uphold the natural laws from those who would disregard them. "The first power, of doing whatsoever he thought fit for the preservation of himself and the rest of mankind, he gives up to be regulated by laws made by the society, so far forth as the preservation of himself and the rest of that society shall require." ${ }^{73}$

Locke was no impractical idealist. He realized that not all men would adhere to the principles set forth in the natural laws. Locke's proposal is that the state, as the representative of every man, would force adherence to the natural laws. "The execution of the Law of Nature is in that the state, put into being by every man's hands, has the right to punish the transgressors of that law to such a degree, as it may hinder its violation." 74

70. See Leonard Tivey, The Nation State 183 (1981).

71. See id. at 71-79.

72. One commentator wrote on Locke's theory:

This does not mean that the state of nature is, in fact, a condition of peace and safety, but that is not the subject presently being considered. Rather, what Locke is attempting to show is that there is a moral standard that God has given to individuals in their natural condition... prohibiting them from taking any action that would harm another individual. Natural law obliges them to act in a manner that would preserve mankind in general.

RICHARD ASHCRAFT, LOCKE'S TWO TREATISES OF GOVERNMENT 101 (1987).

73. JOHN LOCKE, OF CIVIL GOVERNMENT 181 (New York, E. P. Dutton and Co. 1924).

74. Id. at 7 . 
Today, Locke would see such individuals as Usama Bin Ladin and Saddam Hussain as clear transgressors of one of the most sacred of all natural law principles-the preservation of and respect for life. Locke's natural law theory, hand-in-hand with the juris ad vitae formulation, supports the use of force against such targets. While the juris ad vitae theory rests upon the independent duty of the state towards its citizens, Locke described this relationship as the state's responsibility to enforce the natural rights handed down by God to man.

Jean Jacques Rousseau's political ideas were the foundation not only for the French Revolution, but also for much of the subsequent writings of America's Madison and Jefferson. ${ }^{75}$ Rousseau's theories on mankind are at the opposite end of the spectrum from those of Hobbes. Rousseau saw man in his natural state as a kind and gentle creature. For Rousseau, the rise of the state introduced vice into the peaceful existence of man. Rousseau's famous quote "humans are born free, but everywhere we find them in chains" gives his opinion of the utility of the state. ${ }^{76}$

Rousseau's answer to those evils which result from man organizing into society was for the individual to be as free from governmental regulation and intrusion as possible. The state, therefore, should only perform those functions that are absolutely essential to the group. All other functions should remain with the citizens.

Despite his differences with Hobbes, Rousseau himself agrees with the origins of the state. Rousseau wrote that the social contract between the state and man is made at the point where "the strength of each individual is insufficient to overcome the resistance of the obstacles to his preservation." 77 In other words, men initially formed states for reasons of self-preservation. But once these states are formed the nature of man changes, "the passing from the state of nature to the civil state produces in man a very remarkable change, by substituting justice for instinct in his conduct and giving to his actions a moral character which they lacked before."78

Although Rousseau continued to describe his ideal state and the complex interplay between individual liberty and the necessity for the social order, at the very foundation of his analysis he recognized that states exist to ensure the security of their nationals.

All of the social contract theorists (Hobbes, Locke, and Rousseau) agreed that men contract out of the state of nature and into political bodies because of the threat posed to their existence by other organized groups of

75. See MoORS, supra note 66, at 13.

76. Id. at 15 (quoting the SOCIAL CONTRACT, book 1, Chapter 1).

77. Jean-Jacques Rousseau, The Social Contract 59 (Maurice Cranston trans., 1968).

78. Id. at 64 
individuals. ${ }^{79}$ Plato, Aristotle, Hobbes, Locke, and Rousseau may all have had different theories on the nature of man and the best way in which he can govem himself and his fellow man, but all agreed on one basic premise: the state, at its most basic level, exists to protect the individual citizen from outside harm. This is the premise upon which juris ad vitae is based: the idea that, regardless of how international law describes the use of force against a terrorist target, a state will continue to fulfill its duties to its citizens. To do otherwise would void the very foundations for its existence.

This is not to suggest that Plato, Aristotle, Hobbes, Locke, and Rousseau contemplated international law theories of responsibility when espousing their great theories and ideas. Each philosopher focused on the unique relationship between the state and the citizen, inside the borders of the state. Arguing from analogy, however, their intra-state legal doctrines can readily take on international significance. If the state exists or evolved to give protection to its citizens, the fact that the threat exists outside of its recognized borders should not negate the reason for its existence.

The juris ad vitae justification for the use of force focuses on this affirmative obligation that the state owes to its citizens, as opposed to the responsibility one state may or may not owe to another state under the concept of state responsibility. ${ }^{80}$

Juris ad vitae may be better understood as representing the mirror image of the international law concept of vicarious responsibility previously discussed. The vicarious responsibility theory requires states to take affirmative responsibility to stop their private citizens from injuring another nation. However, obligations and responsibilities always flow in a two-way direction. For example, the lawyer's responsibility to his client to provide competent legal advice is offset by the client's obligation of prompt payment of the bill. Therefore, if the state has the international legal responsibility to protect other nations from its citizens, the converse must be true. The state must have the international legal responsibility of protecting not itself (self-

79. BRIAN R. NELSON, WESTERN POLITICAL ThOUght 194 (1982).

80. It is crucial not to confuse the related, but separate ideas, of a state responsibility towards another state and the juris ad vitae concepts. This concept of state responsibility has also been recognized by the judicial body organized by the League of Nations in the Chorzow Factory decision of 1928:

Whenever a duty established by any rule of intemational law has been breached by act or omission, a new legal relationship automatically comes into existence. This relationship is established between the subject to which the act is imputed, who must "respond" by making adequate reparation, and the subject who has a claim to reparation because of the breach of the duty. International responsibility may be incurred by direct injury to the rights of a state and also by a wrongful act or omission which causes injury to an alien.

Chorzow Factory Case, P.C.I.J. Series A, No. 9, 24-25 (1927) (emphasis added). 
defense), but its citizens from serious harm-be it from another nation (weapons of mass destruction) or from the international terrorist who is bent upon slaughter of the innocent. ${ }^{81}$

\section{CONCLUSION}

The international terrorist strikes not at the sovereignty or survival of the nation, but rather at the citizens that make up the state. They seek not to destroy the state, but to change or influence its policies. The legal justification of self-defense is insufficient in the context of combating terrorist threats because of this reason.

The doctrine of juris ad vitae lends itself well to the pre-emptive strikes against development centers for weapons of mass destruction controlled by unstable or dangerous regimes as well as the international terrorist. Although no imminent threat may exist (which could well justify a self-defense theory), the affirmative obligation of the state to its citizens provides adequate justification for the use of force. From the very origins of the nation-state, political philosophers have recognized the affirmative duty of the state towards its citizens.

Obviously, the above proposal presents a full spectrum of problems. What represents an unstable regime? To what extent may force be utilized? Can a purely civilian research center which could possibly be utilized for chemical weapons research be destroyed? What about weapons of mass destruction programs in their infancy? What action can governments take against semi-stable regimes, such as Iran in 1979, that appear headed for instability?

The above questions are those to be discussed and debated among the policy makers of the nation-state. Most are fact-specific, and like selfdefense, will require substantive evidence before acceptance by the

81. It is granted that neither the current domestic government theories nor the international law covering state versus state responsibility by themselves support the proposition that a state may intrude upon the sovereignty of another state to ensure the safety of its citizens abroad or at home. Domestically the United States has fulfilled its duty and passed laws against terrorism. Internationally, the United States has entered into several treaties concerning the proliferation of weapons of mass destruction and the punishment and extradition of terrorists. In addition, if the United States could prove that Libya or Sudan breached its international duty to the United States by allowing its citizens or others under their control to harm U.S. citizens, damages could be sought in the legal arena. Still the above framework for preventing terrorist violence and the spread of weapons of mass destruction has proved itself insufficient. With the international terrorist now operating on the outer fringes of war-tom states with no effective central government, the value of extradition treaties is slight. U.S. domestic laws can do little to punish the individuals whom destroyed the embassies in Kenya and Sudan. Juris ad vitae recognizes and seeks to provide a legal framework for the practical reality that states will not allow the random slaughter of their citizens, regardless of the location of the threat. It is a new name used to describe an age-old concept of state practice. 
international community. Should that analysis and subsequent decision amount to a serious threat to the citizens of a nation, juris ad vitae provides legal justification for the use of force to eradicate the threat.

The international standard for what constitutes a state's valid use of force in self-defense has been clearly established. Case law, state practice under customary law, and the U.N. Charter all point to a clear international standard requiring imminence before the use of force in self-defense. While many states over the last one hundred years have challenged that standard and made the claim of self-defense, inevitably when the international community measured the states' assertions against the standard (be it at Nuremberg or in the Security Council) they were found wanting. Juris ad vitae originates from the very foundations of the modern democratic state. Above all else, the state exists to ensure the survival of its citizens. 
